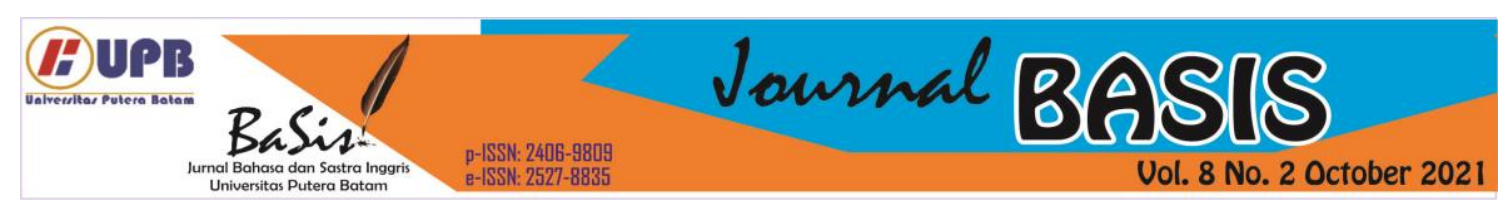

\title{
LANGUAGE CONTEXT NAMING SYSTEM BATAK TOBA CULTURE
}

\author{
Dairi Sapta Rindu Simanjuntak \\ Universitas Putera Batam (UPB), Batam, Indonesia \\ saptadairi@gmail.com \\ Yunisa Oktavia \\ Universitas Putera Batam (UPB), Batam, Indonesia \\ Yunisa@puterabatam.ac.id
}

\begin{abstract}
A name as part of a language used as a marker of a person's identity. The name will also show the culture of the owner of the name. For example, if you hear the names Johannes, Markus, Samsul, Pardomuan, Rumondang, Sujono and Paijo, it will at least give us an idea of the religion or ethnicity of the owners of these names. In this case, the author will try to uncover the naming system on the Batak Toba ethnic group. In Batak Toba culture itself the naming system is given to a person more than once according to the status of the individual. From birth to death, a person will get several names. The purpose of this study is to describe or describe the Batak Toba ethnic naming system. Data collection is done by capable methods, notes, and records. The capable method of fishing technique is used to dig up data from informants. The data that has been obtained is recorded and simultaneously recorded. For this method of ability the author selected two informants who were 62 years old. The naming system in batak toba culture is (1) naming in the period before acquiring offspring; (2) Giving a name before being given the real name (prename), (3) Goar Sihadakdanahon (real name / since birth). In goar sihadakdanahon there are several examples of naming taken from the names of the week found in huria Christian Batak Protestant, especially for those who adhere to Christianity. The names are Trinitatis, Letare, Judika, Rogate, Advent, Exaudi, Sebtu Egatima, Seksagesima, Estomihi, Invokatif, Renimiscere, Okuli, Palmarum, Quatimodogenic, Nisericordiasdomini, Jubilate, Kantate, Ephipanias, and Pentekosta, (4) Panggoaran (name of the eldest child/grandson), (5) Goar-goar (nickname), (6) Marga (family name/relative) (7) Naming by Origin or place of birth.
\end{abstract}

Key words: naming system, culture, Batak Toba

\section{INTRODUCTION}

The Indonesian nation is a very diverse country. This plurality is evident from the social life of people who come from various cultural systems. In the reality of the plurality of our nation's culture, there are currently at least four types of our culture, namely (1) ethnic culture, (2) a new culture rooted in ethnic culture or recent culture, (3) ethnic culture directly influenced by foreign culture or ethnic-foreign culture, and (4) a new culture oriented to foreign culture or new culture (Sibarani, 2004: 22).

Ethnic culture is the original culture of the Indonesian nation that we still 
find easy to find because the culture is still maintained by the community. Currently, the ethnic group in Indonesia is approximately 700 . The number also indicates that the number of ethnic languages that exist is also less than 700 ethnic languages.

The new culture is a culture that is newly known to our nation, but still has ethnic nuances. In terms of language, Indonesian including new-ethnic cultures because its main root is Malay. Ethnic-foreign cultures such as ethnic music are currently widely collaborated with foreign music. Likewise with modern clothing that uses ethnic materials or motifs. New culture is a new culture oriented to foreign cultures that have clearly seemed to bring about change, especially the younger generation today. For example, diet, the way of dressing has led to a "modern" culture (Simanjuntak, 2015).

Based on the description above, it is concluded that a cultural system can undergo changes because humans or their society undergo changes from various aspects of life. For example, way of life, customs, social understanding, and community.

Acculturation is a social process that arises when a society is faced with the element of a foreign culture so that the element of foreign culture will gradually be accepted into its own culture without eliminating the cultural personality. Social processes that occur in communities of different cultural backgrounds that cause the culture of the community group to be transformed into a mixed culture.

In this case, the cultural system also greatly affects the people in naming (name-giving system). Certain ethnic communities certainly have special considerations in naming children or offspring. Whether the name is taken because it has a special meaning in its culture, or the naming is behind the atmosphere at birth, the merging of the names of both parents, the location of residence, idol figures, hope, or others.

In Batak Toba ethnicity, the system of naming children / descendants is very important. The system of naming certainly has considerations according to the culture of the community. Batak Toba people are known as an ethnic group that is very thick with traditional nuances and is known to be very flattering of cultural values / customs. One of them is from the name-giving system, although today there are very many parents who give names to their children by adopting a system of naming foreign cultures.

A name as part of a language used as a marker of a person's identity. The name will also show the culture of the owner of the name. For example, if you hear the names Markus, Benedictus, Samsul, Sarwendah, Poltak, Lamtiur, Sumarno, and Parto, it will at least give us an idea of the religion or ethnicity of the owners of these names. Even if there are various deviations, it is caused by a certain intent or background.

In this case, the author will try to uncover the naming system on the Batak Toba ethnic group. In Batak Toba culture itself the naming system is given to a person more than once according to the status of the individual. From birth to death, a person will get several names. That is behind the author to study the naming system on the Batak Toba ethnicity and its meaning will be outlined in this paper.

\section{LITERATURE REVIEW Cultrure}

Today, the role of culture is increasingly important in human life as the development of human resources and the development of the character of the nation. Moreover, at this time, the 
government is aggressively implementing a character-based curriculum by raising culture as the main issue in the development in question.

Culture is in fact so complex that experts give a diverse understanding, understanding of the definition of spirituality. First the notion of culture was introduced by Taylor in 1981 (Taylor in Robert, 2004: 2), but the understanding of culture according to Taylor is very broad covering an entire field that includes knowledge, beliefs, arts, morals, laws, customs, and other abilities acquired by humans as members of society. In contrast to Wilson (Wilson in Robert, 2004: 2) says that culture is knowledge that is transmitted and disseminated socially, both existential, normative and symbolic, reflected in the actions (act) and objects of human works (artifacts).

As mentioned above, culture has long been the subject of discussion that raises many differences of opinion from experts and cultural observers. In fact, a thing that must be answered by cultural experts pleased with the understanding of culture is for whether culture is for its people or why society needs to maintain its culture. Pragmatically, culture is the habit of a society that is useful for maintaining and developing its way of life (Simanjuntak et al., 2020)

Based on the above opinions, it can be concluded that culture is the whole habit of a group of people reflected in the knowledge, actions, and results of his work as social creatures used to understand his environment and who guide his behavior to achieve peace and / or welfare of his life.

\section{Language}

Language belongs to a member of society, language is reflected in human ideas, actions, and works; Language also serves as a means for humans to play, act, interact, and function in people's lives; Language must be learned; Language can also make others happy through the message it conveys.

Kridalaksana (1983:17) says that "Language is an arbitrary lambing system used by a society to cooperate, interact, and identify." Contrary to the above opinion, Keraf (1985: 16) said that language is a means of communication between members of society, in the form of sounding, by human speech tools.

While in the Great Dictionary of Indonesian mentioned that the notion of language is an arbitrary sound lambing system used by members of a society to cooperate, interact, and identify themselves.

From the various definitions above, it can be noted that in essence the language is a sign or system of symbols, as a means to communicate, and owned by humans or groups of people as language users.

\section{Naming System}

Until the end of the 20th century most Indonesians did not have a family name. Usually children inherit their father's name (or their mother in Minangkabau culture). Partially married women adopt their husband's name, but it is not uncommon to stick with their last name, or simply not adopt their husband's name. Therefore, often husband and wife have a different last name.

Family names have many variations. The people of North Sumatra have their own clan name, the Javanese people partly have only a single name (sometimes followed by their father's name - patronymic), the ChineseIndonesian has a Chinese name. That's why the sorting system used in Indonesia (as in the phone book) almost 
all sorts names by people's first names, and Indonesians are used to thinking/attaching importance to a person's first name rather than their last name being reversed with a EuropeanAmerican country that attaches importance to one's last name and sorts names by their last name.

Indonesians give their children the name Indonesia in various ways. With more than 17,000 islands and diverse cultures and regional languages, Indonesia does not have one particular rule in naming. Certain tribes have surnames that are passed down from parents to their children. Other tribes do not know family names.

The concept of surnames is not known in some Indonesian cultures, such as Javanese culture. Therefore, many people to date have only one name, namely the name of the gift. If they then leave or settle in countries that require each resident to have at least two names (grant names and surnames), difficulties may occur. The solution that is usually taken is to repeat the name twice.

Some other cultures have rules regarding surnames or surnames. In Batak and Minahasa cultures for example, the father's surname is passed down to his children (patrilineal) for generations. In Minangkabau culture, married men will be given the title behind their names, while women in general do not have a title. ArabIndonesians also give surnames behind his name, such as Hambali, Shihab, Assegaf, etc.

Then the Javanese, Balinese, and some Madurese people, as well as Sundanese also often use a name derived from Sanskrit. Since the policies of Suharto's rule in the New Order era, Chinese people have been prohibited from using Chinese names in state administration. So that the majority of them have an Indonesian name next to a Chinese name. In its Indonesian name, the Chinese often slip the surname and family. Some examples: Sudono Salim (clan: Liem), Anggodo Widjojo (clan: Ang).

\section{RESEARCH METHOD}

Research methods are regular ways used to carry out an activity to be achieved in accordance with the desired or systemal work to facilitate the implementation of an activity to achieve the desired goal. (Farchan Arief, 1987:415).

For the discussion of the problems raised in this study, relevant data is needed. Data collection is done by capable methods, notes, and records. The capable method of fishing technique is used to dig up data from informants. The data that has been obtained is recorded and simultaneously recorded. For this method of ability the author selected two informants who were 62 years old. Both informants as a source of information are considered representative and also to avoid engineering the adjustment of data desired by researchers So in this study, in addition to the two informants, researchers also use themselves as a source of data because the researcher is also a Batak Toba ethnicity.

\section{RESULT AND DISCUSSION}

In Batak Toba culture, there are several naming systems, namely:

a) Naming in the time before acquiring offspring

Batak Toba people generally give names to married couples who are newly married and have long been married but do not have children. It can be said that this naming is given to those who are waiting for the presence of offspring. There are two types of 
naming in this case. The name depends on the situation that occurs in the family. First, the naming of a couple who have not had children and have not obtained signs of acquiring offspring. For example, after a medical examination, there is no fetus in the wife's womb. In this case, then he pinned the call Nai Harapan (Mother of Hope). Likewise to the husband pinned the call Ama Harapan (Father of Hope). The nickname was given as a form of prayer for their dreams to get offspring. Second, the naming given to a couple who have obtained signs will get offspring. For example, medical examinations have been carried out. The fetus in the wife's womb has developed. Or a family is expecting the birth of their child. In this situation, to them pinned the call Nai Paima (Mother Waiting). Likewise to the husband pinned the call Ama Paima (Mr. Waiting). This means that the nickname is given as a sign that they are looking forward to the birth of their child.

The naming doesn't stop there. If the husband or wife is the firstborn in the family, then the naming will also be pinned to their parents. To their parents will be given the name Отри Harapan Baoa (Grandpa Hope) or Ompu Paima Baoa (Grandpa Waiting) and Ompu Harapan Boru (Granny Hope) or Ompu Paima Boru (Grandma Waiting). That's how the naming goes all the way to the great-grandfather if their position is all the firstborn.

b) Giving a name before being given its real name (pre-name)

This name is given to a newborn child. By itself, a boy will be named Unsok and a girl named Butet. This name will remain in use until the child is finally given his real name. In reality, many parents have prepared a name for a newborn child, but because the majority of the Batak Toba tribe adheres to Christianity, the name has not been considered valid if the child has not been registered religiously (baptized). So, even if a child already has a real name, that name cannot be used until he or she is religiously registered (baptized). The child will still be called Unsok for men, and Butet for girls. So, the child is entitled to use his real name after he is baptized religiously. In other words, his real name was used after the child was baptized religiously in the church.

c) Goar Sihadakdanahon (real name/since birth)

This name is given to parents to children since childhood. Like Bonar, Rumondang. This is the name called "personal name". This name will be used until someone dies. Considering the Batak Toba ethnic group is majority Christian, there are times when parents give names to children by being motivated by the names of weeks in Christianity. There are at least 47 names a week in Christianity. The name of the week has its own meaning. Naming the name of the week in the trust to a child in the hope that the child will be or of the same character as the meaning of the week. Here are the names of the weeks in the Christian faith.

\begin{tabular}{|c|c|}
\hline Name of the week & Meaning \\
\hline Trinitatis & Sitolu sada (trinity) \\
\hline Letare & Marlas ni roha (jubilant) \\
\hline Judika & $\begin{array}{l}\text { Luluhon/boan ahu Tuhan } \\
\text { (bring me God) }\end{array}$ \\
\hline Rogate & Martangiang (pray) \\
\hline Exaudi & $\begin{array}{l}\text { Sai tangihonma soaraku } \\
\text { Tuhan (listen to me Lord) }\end{array}$ \\
\hline Advent & $\begin{array}{l}\text { Pangaradeon/paimahon } \\
\text { (waiting) }\end{array}$ \\
\hline Ephipanias & $\begin{array}{l}\text { Idaonta do Debata (we'll } \\
\text { see god) }\end{array}$ \\
\hline Sebtuegatima & $\begin{array}{l}\text { Pitu pulu ari andorang so } \\
\text { haheheon (seventy days }\end{array}$ \\
\hline
\end{tabular}




\begin{tabular}{|c|c|}
\hline & before the resurrection) \\
\hline Seksagesima & $\begin{array}{l}\text { Onom pulu ari andorang so } \\
\text { haheheon (sixty days before } \\
\text { the resurrection) }\end{array}$ \\
\hline Estomihi & $\begin{array}{l}\text { Sai ho ma gabe partano } \\
\text { batoanku (You are the } \\
\text { support of my life) }\end{array}$ \\
\hline Invokatip & $\begin{array}{l}\text { Jouonna ma ahu, jala } \\
\text { alusanhu ma ibana (God } \\
\text { will call me, and I will } \\
\text { answer it) }\end{array}$ \\
\hline Reminiscere & $\begin{array}{l}\text { Sai ingotma akka denggan } \\
\text { ni basana (remember all His } \\
\text { goodness) }\end{array}$ \\
\hline Okuli & $\begin{array}{l}\text { Sai tongtong do } \\
\text { mangaranapi mataku tu } \\
\text { jolom (My eyes will always } \\
\text { be on him) }\end{array}$ \\
\hline Palmarum & $\begin{array}{l}\text { Mare-mare/partinaonan } \\
\text { (suffering) }\end{array}$ \\
\hline Paskah & Haheheon (resurrection) \\
\hline Ouatimodogeniti & $\begin{array}{l}\text { Songon poso-poso na } \\
\text { imbaru tubu (like a newborn } \\
\text { child) }\end{array}$ \\
\hline Nisericordiasdomini & $\begin{array}{l}\text { Gok asi ni roha ni Jahoba } \\
\text { do tano on (god is merciful } \\
\text { and loving of the universe) }\end{array}$ \\
\hline Jubilate & $\begin{array}{l}\text { Marolop-olop tu Debatama } \\
\text { sandok tano on (rejoice in } \\
\text { God, the whole universe of } \\
\text { nature.) }\end{array}$ \\
\hline Kantate & $\begin{array}{l}\text { Endehon hamu ende na } \\
\text { imbaru (sing a new song.) }\end{array}$ \\
\hline Pentakosta & Hananaek (increase) \\
\hline
\end{tabular}

The names of the weeks above are one of the things that are considered by parents in the system of naming their children. Giving this week's name becomes a nickname / actual name to the child with the intention that the child can become human according to the meaning of the week. This week's name may also be behind the week of the child's birth. For example, if a child is born at the third week of December, the child will be named Advent, Adventina, Adeventinus, which means that the week is the week of waiting for the birthday of the Lord Jesus. If parents want their children to be children who pray diligently, then parents will give the name Rogate. Another example, if a child is born in the midst of a family, and the birth brings joy to the midst of the family, it will be named Letare which means joy.

\section{d) Naming by region of birth}

In the actual name-giving system, Batak Toba ethnic also know the system of naming based on the region of birth. In ancient times, for example, in Toba, Balige region there were children born in the village of Parsuratan. The name of the village was used as the name of the child and to this day, the name is passed down to his descendants. A simpler example is the author's name, Dairi. The background given the name to the author is because the author was born in Dairi regency.

Naming systems also often incorporate several elements, namely the region of birth, the order of children in the family, and hope. For example Dairi Sapta Rindu Simanjuntak. Dairi was given because the owner of the name was born in Dairi Regency, while the name Sapta was adopted from the Sanskerta language which means seven, the name was given because the owner of the name was the seventh child in the family, and the last was Longing, the name was given because parents goosed the birth of the child. While the last, Simanjuntak, is a clan descended from ancestors (patrilineal).

e) Panggoaran (name of the eldest child/grandson)

This name is an additional name that the community gives directly to parents by calling the name of their eldest child or grandchild. For example, a father named Pak Sabam and a mother named Rina's mother have four children. The biggest one is called Rumondang. So the father is no longer called Mr. Sabam, but Pak Rumondang (in Batak Toba Ama Rumondang). And so did Rina's mother. She was no longer 
called Rina's mother, but Mother Rumondang (Batak Toba Nai Rumondang). And if the married couple already has the largest grandson named Sihol, then the married couple will be given an additional name such as $O m p u$ Sihol / Grandpa or Sihol's grandmother.

f) Goar-goar (sobriquet)

It is an additional name given by the crowd to someone who has certain privileges, habits, occupations or traits. There are two types of this name, namely nicknames based on positions/titles/professions, and nicknames based on the nature of a person. The first nickname of bhampir is the same as "honorary title", and the second nickname equals innuendo. Nickname of honorary names such as Datu, Doctor, Proffesor. For example, Mr. Dairi Simanjuntak has the title of Professor. Incidentally, in his village, only he has the title of Professor. So, the people in kampong call or give the nickname Professor. The name of the satire for example:

\begin{tabular}{ll}
\hline $\begin{array}{l}\text { Tokke } \\
\text { Haminjon }\end{array}$ & $\begin{array}{l}\text { given to someone for looking } \\
\text { like a frankincense merchant }\end{array}$ \\
\hline Pellus & $\begin{array}{l}\text { in Batak Toba this title is given } \\
\text { to someone because of his } \\
\text { appearance or person is small, } \\
\text { thin, using pants and shirt / shirt } \\
\text { never fits / loose if worn because } \\
\text { he is thin } \\
\text { given to someone because it has } \\
\text { a distended stomach. } \\
\text { given to a person because it has } \\
\text { a short body } \\
\text { given to someone for having } \\
\text { black skin } \\
\text { given to people who are } \\
\text { stubborn, ignorant, and do not } \\
\text { hear advice }\end{array}$ \\
\hline
\end{tabular}

g) Marga (family name/relative)

It is a name given based on linear kinship based on the patrilineal genological lineage of one grandmother. For example, there used to be a person named Pasaribu; Then all the descendants use the Pasaribu clan as their surname to signify that they are descendants of Pasaribu's ancestors. So is the case with Simanjuntak, Hutagaol, Sihombing, Siregar, and many more. At least, in the Batak Toba ethnicity there are more than 400 clans. This clan will be pinned behind the actual baptismal name.

h) Naming after death

This naming is the culmination of all naming systems in Batak Toba culture. In the Batak Toba tradition, a person who dies will get an additional call. The naming is pinned to anyone regardless of background during life. Be it to the rich, officials, the rich, the poor, the young, the old, men, women, all will be pinned the same name as a marker that the person in question has died. The additional nickname is Nahinan (who is gone). In Indonesian society is generally called the deceased.

\section{CONCLUSION}

The new culture is a culture that is newly known to our nation, but still has ethnic nuances. In terms of language, Indonesian including new-ethnic cultures because its main root is Malay. It can be said that a cultural system can undergo changes because humans or their society undergo changes from various aspects of life. For example, way of life, customs, social understanding, and community. In this case, the cultural system also greatly affects the people in naming (namegiving system). Certain ethnic communities certainly have special considerations in naming children or offspring. Whether the name is taken because it has a special meaning in its culture, or the naming is behind the atmosphere at birth, the merging of the names of both parents, the location of residence, figure idol, hope, or others. 
In Batak Toba ethnicity, the system of naming children / descendants is very important. The system of naming certainly has considerations according to the culture of the community. Batak Toba people are known as an ethnic group that is very thick with traditional nuances and is known to be very flattering of cultural values / customs. A name as part of a language used as a marker of a person's identity. The name will also show the culture of the owner of the name. For example, if you hear the names Johannes, Markus, Abdulrahman, Pardomuan, Rumondang, Sujono and Paijo, it will at least give us an idea of the religion or ethnicity of the owners of these names. Even if there are various deviations, it is caused by a certain intent or background. In Batak Toba culture there is a naming system. The naming system is given to a person more than once according to the status of that individual. From birth to death, a person will get several names. The naming system in Batak Toba culture is (1) Naming in the time before acquiring offspring; (2) Giving a name before being given the real name (prename); (3) Goar Sihadakdanahon (real name/since birth). In goar sihadakdanahon there are several examples of naming taken from the names of the weks found in Huria Christian Batak Protestant, especially for those who adhere to Christianity. The names are Trinitatis, Letare, Judika, Rogate, Advent, Exaudi, Sebtu Egatima, Seksagesima, Estomihi, Invokatif, Renimiscere, Okuli, Palmarum, Quatimodogenic, Nisericordiasdomini, Jubilate, Kantate, Ephipanias, and Pentekosta; (4) Naming by region of birth; (5) Panggoaran (name of the eldest child/grandson); (6) Goar-goar (nickname); (7) Marga (family name/relative); and (8) Naming by Origin or place of birth.

\section{REFERENCES}

Kamus Besar Bahasa Indonesia: Edisi Revisi. Jakarta: Depdikbud

Keraf, Goris. 1985. Diksi dan Gaya Bahasa. Jakarta: Gramedia

Kridalaksana, Harimurti. 1983. Kamus Lingustik. Jakarta: Gramedia

Sibarani, Robert. 2004. Antropolinguistik. Medan: Penerbit Poda

Siregar, dkk. (1998). Pemertahanan Bahasa dan Sikap Bahasa: Kasus Masyarakat Bilingual di Medan. Jakarta: Pusat Pembinaan dan Pengembangan Bahasa Departemen Pendidikan dan Kebudayaan

Simanjuntak, D. S. R. (2015). Penerapan Teori Antropolinguistik Modern (Competence, Performance, Indexicality, \& Partisipation) Dalam Umpasa Budaya Batak Toba. Jurnal Basis, 2(2), 71-78. http://ejournal.upbatam.ac.id/index .php/basis/article/view/407/265

Simanjuntak, D. S. R., Widayati, D., \& Sinar, T. S. (2020). The Understanding of Urug Gedang Village Community toward 'Kayu' Lexicon of Pakpakdairi Language. Icels 2019, 115-118. https://doi.org/10.5220/000899460 1150118

Wijana, I.D.P. (2014). "Bahasa, Kekuasaan, dan Resistensinya: Studi Tentang Nama-Nama BadanUsaha di Daerah Istimewa Yogyakarta. Humaniora, 26(1), 56-64. 